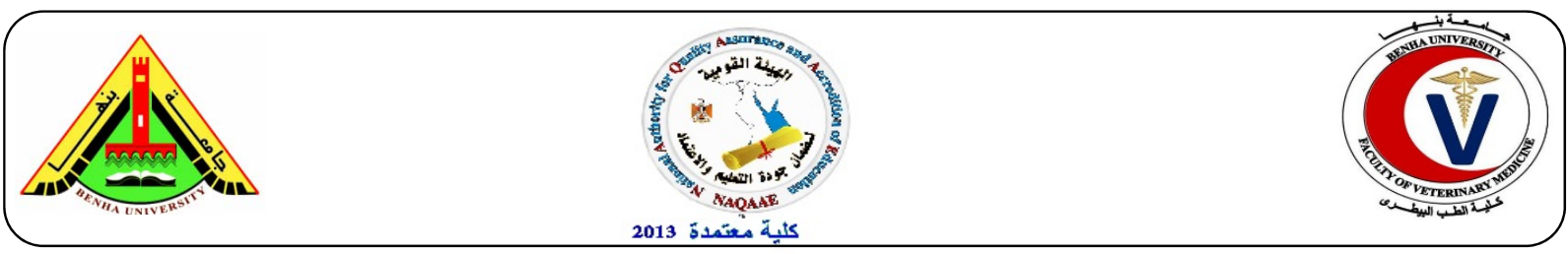

\title{
Biogenic Amines as Serious Residues in Street Vended Foods
}

\author{
Suzan F. Elsisy'; Hemmat M. Ibrahim², Mohamed A. Hassan² and Ali M. Ali ${ }^{1}$ \\ ${ }^{1}$ Animal Health Research Institute, Benha Branch. ${ }^{2}$ Food Hygiene Control Department, Faculty of Veterinary Medicine, \\ Benha University.
}

\section{A B S T R A C T}

One hundred and thirty-five random samples of street vended foods represented by kofta, hawawshi and liver (45 of each) were collected from Benha (15 of each product), Tukh (15 of each product) and Moshtohor (15 of each product) in Kalyobia governorate for determination of their content of histamine and tyramine. The obtained results recorded that, the percentage of occurrence of histamine in Benha city were $73.33,93.33$ and $66.67 \%$ in the kofta, hawawshi and liver samples, respectively. In Tukh center were $86.67,100$ and $73.33 \%$ in the kofta, hawawshi and liver samples, respectively. Whereas in Moshtohor village were 100, 100 and $80.00 \%$ in the kofta, hawawshi and liver samples, respectively. Furthermore, our results showed that the percentage of occurrence of tyramine in Benha city were 86.67, 100 and 73.33 $\%$ in the kofta, hawawshi and liver samples, respectively. In Tukh center were 93.33, 100 and $73.33 \%$ in the kofta, hawawshi and liver samples, respectively. Whereas in Moshtohor village were 100, 100 and $86.67 \%$ in the kofta, hawawshi and liver samples, respectively. It could be inferred that regarding the products contamination, hawawshi represented the highest histamine and tyramine contamination followed by kofta then liver. Regarding the locality, Moshtohor represented the highest contamination of both histamine and tyramine followed by Tukh then Benha city.

Key words: street vendors, liver, histamine, tyramine, meat products.

(http://www.bvmj.bu.edu.eg)

(BVMJ-31(2):262-266, 2016)

\section{INTRODUCTION}

Meat is composed of protein, minerals, fats, vitamins and other bioactive components, and small quantities of carbohydrates. From the nutritional point of view, meat's importance is derived from its high-quality protein, containing all essential amino acids and its highly bioavailable minerals and vitamins (FAO, 2013). Street foods vending is famous to a large number of people as a source of inexpensive, convenient and often nutritious foods for urban and rural poor; a source of attractive and varied foods for tourists and those economically advantaged individuals; and it also provides business opportunities for a very low capital. Street foods vending plays an important role in assuring food security for low-income urban populations (WHO, 2010). In addition, street food vending activities in most developing countries are mostly outside the regulation and protection of the governments. The economic importance of the activities is not well appreciated due to the informal nature of the enterprise and lack of official data on volume of trade involved. Biogenic amines (BA) are natural antinutritional factors and are important from a hygienic point of view as they have been implicated as the causative agents in a number of food poisoning episodes. They are able to initiate various pharmacological reactions. Histamine and tyramine are considered to be the most important biogenic amines occurring in food. Analyses of biogenic amines are important because of their toxicity and considered as an indicator for the degree of freshness or food spoilage (Armağan, 2006).

The aim of the current study is two evaluate the contamination levels of street vended food with biogenic amines and their arability of human consumption.

\section{MATERIAL AND METHODS}

\subsection{Collection of samples:}

A total of 135 random samples of street vended foods represented by kofta, hawawshi and liver (45 of each) were collected from Benha (15 of each product), Tukh (15 of each product) and Moshtohor (15 of each product) in Kalyobia governorate. The collected samples were examined for determination of histamine and tyramine levels.

\subsection{Determination of biogenic amines:}

Two biogenic amines such as histamine and tyramine were determined in all examined samples 
according to the protocol recommended by Krause et al. (1995) and Pinho et al. (2001).

\subsubsection{Reagents preparation:}

Dansyl chloride solution: 500mg of dansyl chloride were dissolved in $100 \mathrm{ml}$ acetone. Standard solutions: Stock standard solutions of the tested amines were prepared as the following: add $25 \mathrm{mg}$ of each standard pure amine (histamine$2 \mathrm{HCl}$, tyramine- $2 \mathrm{HCl}$ Standard solutions: Stock standard solutions of the tested amines were prepared as the following: add $25 \mathrm{mg}$ of each standard pure amine (histamine- $2 \mathrm{HCl}$, tyramine$2 \mathrm{HCl}$ Standard solutions: Stock standard solutions of the tested amines were prepared as the following: add $25 \mathrm{mg}$ of each standard pure amine (histamine- $2 \mathrm{HCl}$ and tyramine-2 $\mathrm{HCl}$ ) were dissolved in $25 \mathrm{ml}$ distilled water individually.

\subsubsection{Extraction of samples and formation of dansylamines (Armă̆an, 2006):}

One hundred $\mu 1$ of each stock standard solution (or sample extract) were transferred to $50 \mathrm{ml}$ vial and dried under vacuum. About $0.5 \mathrm{ml}$ of saturated $\mathrm{NaHCO} 3$ solution was added to the residue of the sample extract (or the standard). Vial was stoppered and carefully mixed to prevent loss- due to spattering. Carefully, $1.0 \mathrm{ml}$ dansyl chloride solution was added and mixed thoroughly using vortex mixer. The reaction mixture was incubated at $55^{\circ} \mathrm{C}$ for $45 \mathrm{~min}$. About $10 \mathrm{ml}$ of distilled water were added to the reaction mixture, then vial was stoppered and shaked vigorously using vortex mixer, the extraction of dansylated biogenic amines was carried out using $5 \mathrm{ml}$ of diethyl ether for 3times again vial was stoppered, shaked for
$11.0 \mathrm{~min}$ and the ether layers were collected in a culture tube using disposable Pasteur pipette. The combined ether extracts were carefully evaporated at $35^{\circ} \mathrm{C}$ in dry bath with aid of current air. The obtained dry material was dissolved in $1 \mathrm{ml}$ methanol and $10 \mu \mathrm{l}$ were injected in High performance liquid chromatography(HPLC), data were integrated and recorded using Chemstation Software program.

\section{RESULTS}

The obtained results in table (1) revealed that the mean value of histamine in the kofta samples were $12.57 \pm 2.08,17.32 \pm 2.91$ and $24.19 \pm 3.56 \mathrm{mg}$ $\%$ in Benha, Tukh and Moshtohor city, respectively. The average concentration of histamine in hawawshi samples were $16.96 \pm 2.72$, $22.06 \pm 3.24$ and $27.75 \pm 3.93 \mathrm{mg} \%$ in Benha, Tukh and Moshtohor city, respectively. The average concentration of histamine in liver samples were $6.28 \pm 1.35,9.89 \pm 1.67$ and $11.04 \pm 1.80 \mathrm{mg} \%$ in Benha, Tukh and Moshtohor city, respectively. Furthermore, according to the safe permissible limit stipulated by Egyptian Organization for Standardization and Quality control "EOS" (2005) for histamine in street vended food products which is $200 \mathrm{ppm}$ in Benha city, the percentage of unaccepted samples in table (2) were 13.33 and $20.00 \%$ in the kofta and hawawshi, while all liver samples were accepted. In Tukh center, the percentage of unaccepted samples were 26.67 , 40.00 and $6.67 \%$ in the kofta, hawawshi and liver samples, respectively.

Table (1): Statistical analytical results of histamine levels (mg \%) in the examined samples of street vended foods. $(n=15)$

\begin{tabular}{lccccc}
\hline \multirow{2}{*}{$\begin{array}{l}\text { Locality / Sandwich } \\
\text { No }\end{array}$} & $\%$ & Min. & Max. & Mean \pm S.E* \\
\hline Benha city: & 11 & 73.33 & 2.7 & 24.6 & $12.57 \pm 2.08$ \\
Kofta & 14 & 93.33 & 4.0 & 29.3 & $16.96 \pm 2.72$ \\
Hawawshi & 10 & 66.67 & 1.5 & 13.4 & $6.28 \pm 1.35$ \\
Tukh center: & 13 & 86.67 & 3.1 & 30.5 & $17.32 \pm 2.91$ \\
Kofta & 15 & 100 & 5.7 & 36.1 & $22.06 \pm 3.24$ \\
Hawawshi & 11 & 73.33 & 1.9 & 21.7 & $9.89 \pm 1.67$ \\
Liver & 15 & 100 & 4.1 & 39.8 & $24.19 \pm 3.56$ \\
Moshtohor village: & 15 & 100 & 5.9 & 41.4 & $27.75 \pm 3.93$ \\
Kofta & 12 & 80.00 & 2.8 & 22.5 & $11.04 \pm 1.80$ \\
Hawawshi & & & & & \\
Liver & &
\end{tabular}


Table (2): Acceptability of the examined samples of street vended foods based on their levels of histamine. $(\mathrm{n}=15)$

\begin{tabular}{|c|c|c|c|c|c|c|c|}
\hline \multirow{2}{*}{ Locality } & \multicolumn{3}{|c|}{ Maximum Permissible Unaccepted Kofta } & \multicolumn{2}{|c|}{ Unaccepted Hawawshi } & \multicolumn{2}{|c|}{ Unaccepted Liver } \\
\hline & Limit $(\mathrm{mg} \%)^{*}$ & No. & $\%$ & No. & $\%$ & No. & $\%$ \\
\hline Benha & 20 & 2 & 13.33 & 3 & 20.00 & - & - \\
\hline Tukh & 20 & 4 & 26.67 & 6 & 40.00 & 1 & 6.67 \\
\hline Moshtohor & 20 & 5 & 33.33 & 8 & 53.33 & 1 & 6.67 \\
\hline Total (45) & 20 & 11 & 24.44 & 16 & 35.56 & 2 & 4.44 \\
\hline
\end{tabular}

* Egyptian Organization of Standardization "EOS" (2005)

Table (3): Statistical analytical results of tyramine levels (mg \%) in the examined samples of street vended foods. $(\mathrm{n}=15)$

\begin{tabular}{lccccc}
\hline \multirow{2}{*}{ Locality / Sandwich } & \multicolumn{2}{c}{+ ve samples } & Min. & Max. & Mean \pm S.E* \\
& No & $\%$ & & & \\
\hline Benha city: & 13 & 86.67 & 3.3 & 37.0 & $19.21 \pm 2.85$ \\
Kofta & 15 & 100 & 5.8 & 49.6 & $27.59 \pm 3.31$ \\
Livawshi & 11 & 73.33 & 2.0 & 22.9 & $10.64 \pm 1.18$ \\
Tukh center: & 14 & 93.33 & 3.9 & 41.5 & $24.17 \pm 2.91$ \\
Kofta & 15 & 100 & 6.2 & 58.3 & $31.91 \pm 3.62$ \\
Hawawshi & 11 & 73.33 & 2.7 & 25.1 & $12.75 \pm 1.16$ \\
Liver & 15 & 100 & 4.7 & 52.6 & $31.02 \pm 3.34$ \\
Moshtohor village: & 15 & 100 & 6.5 & 70.2 & $38.86 \pm 4.11$ \\
Kofta & 13 & 86.67 & 3.0 & 31.7 & $15.29 \pm 1.76$ \\
Hawawshi & & & & &
\end{tabular}

S.E* $=$ Standard error of mean

Table (4): Acceptability of the examined samples of street vended foods based on their levels of tyramine. $(\mathrm{n}=15)$

\begin{tabular}{lccccccc}
\hline Locality & \multicolumn{3}{c}{$\begin{array}{c}\text { Maximum Permissible } \\
\text { Limit }(\mathrm{mg} \%)^{*}\end{array}$} & \multicolumn{2}{c}{ Unaccepted Kofta } & Unaccepted Hawawshi & \multicolumn{3}{c}{ Unaccepted Liver } \\
& 20 & No. & $\%$ & No. & $\%$ & No. & $\%$ \\
\hline Benha & 20 & 26.67 & 5 & 33.33 & 1 & 6.67 \\
Tukh & 20 & 4 & 26.67 & 6 & 40.00 & 1 & 6.67 \\
Moshtohor & 7 & 46.67 & 9 & 60.00 & 3 & 20.00 \\
Total (45) & 20 & 15 & 33.33 & 20 & 44.44 & 5 & 11.11 \\
\hline
\end{tabular}

* Egyptian Organization of Standardization "EOS" (2005)

In Moshtohor village, the percentage of unaccepted samples were $24.44,35.56$ and $4.44 \%$ in the kofta, hawawshi and liver samples, respectively. In addition, the average concentration of tyramine in the kofta samples were $19.21 \pm 2.85,24.17 \pm 2.91$ and $31.02 \pm 3.34 \mathrm{mg} \%$ in Benha, Tukh and Moshtohor city, respectively.

\section{DISCUSSION}

From the obtained results, the collected street vended food samples (kofta, hawawshi and liver) were highly contaminated with toxic biogenic amines residues (histamine and tyramine). Regarding the products contamination, the highest histamine contamination was in hawawshi followed by kofta then liver. The current results in histamine relatively agree with those recorded by Faten et al. (2011) recorded that the average concentration of histamine in random samples of 
fast food (grilled meat) was $8.94 \pm 0.31 \mathrm{mg} \%$. Giroto et al. (2010) concluded that the presence of histamine in food especially sausage with level of 50-100 ppm. Gençcelep et al. (2008) found that the histamine content in Turkish dry fermented sausage was under $50 \mathrm{mg} / \mathrm{kg}$ in $80 \%$ of the samples, while it was over $100 \mathrm{mg} / \mathrm{kg}$ in only one sample. El-Mossalami et al. (2011) recorded that the histamine concentration in dry sausage was 2.68 to $16.47 \mathrm{mg} / 100 \mathrm{~g}$, while in luncheon varied from not detected to $3.65 \mathrm{mg} / 100 \mathrm{~g}$. EFSA (2011) recorded that the mean value of histamine in ripened meat products was $5.9-6.4 \mathrm{mg} / \mathrm{kg}$. In contrast, our results disagree with those recorded by Fletcher et al. (1998) found that the histamine levels in two examined samples of smoked fish were 346.4 and $681.8 \mathrm{mg} / \mathrm{kg}$. In addition, biogenic amines act as the main cause of some toxic symptoms, such as headache, migraine, diarrhea, hypotension and unconsciousness and cardiac arrhythmia in severe cases. In addition, the most important one of them, is histamine which causes the most serious physical problems, for example, rashes, sweating and respiratory disorders (Wigand et al., 2012). From our results, the highest tyramine contamination was in hawawshi followed by kofta then liver. Our results agree with those recorded by Rekka (2002) observed that the tyramine level in sausage samples was $29.81 \mathrm{mg} / 100 \mathrm{~g}$. The obtained results disagreed with those recorded by Giroto et al. (2010) surveyed that the presence of tyramine in foods especially in sausage with level of 100-200 ppm. Faten et al. (2011) recorded that the average concentration of tyramine in random samples of fast foods as grilled meat was $16.29 \pm 0.97 \mathrm{mg} \%$. Kurt and Zorba (2010) found that tyramine in fresh meat was $15.4 \mathrm{mg} / \mathrm{kg}$., El-Mossalami et al. (2011) observed that, in food products (dry sausage and luncheon) tyramine was ranging between not detected to $15.32 \mathrm{mg} / 100 \mathrm{~g}$ in dry sausage and ranging between 0.11 to $0.82 \mathrm{mg} / 100 \mathrm{~g}$ in luncheon Gençcelep et al. (2008) recognized that the tyramine content in Turkish dry fermented sausage was $2.4 \pm 0.06 \mathrm{mg} / \mathrm{kg}$ and Vinci and Antonelli (2002) recorded that the average concentration of tyramine in meat samples (adult bovine) was 10.71 $\pm 0.31 \mathrm{mg} / \mathrm{kg}$. Furthermore, the consumption of foods with excessive amounts of tyramine and histamine, can cause toxic symptoms such as increase in blood pressure. Moreover, although putrescine and cadaverine are not toxic in nature, these compounds may cause risk for human health, through their action, by stimulating the toxic effects of tyramine and histamine (Triki et al., 2012).
It could be inferred that regarding the locality, Moshtohor represented the highest contamination of both histamine and tyramine followed by Tukh then Benha city. Regarding the product contamination, hawawshi represented the highest contamination of both histamine and tyramine followed by kofta then liver.

\section{REFERENCES}

Armağan, Ö., 2006. Current analytical methods for the determination of biogenic amines in foods. Food Chemistry 103, 1475-1486.

EFSA, 2011. European Food Safety Authority \& Panel on Biological Hazards (BIOHAZ) Scientific opinion on risk base control of biogenic amine formation in fermented foods. EFSA Journal 9, 2393-2486.

Egyptian Organization for Standardization and Quality control "EOS", 2005. Detection of poisons and control. Report No. 1796.

El-Mossalami, H.H.A., El-Mossalami, E.I.K., Abdel-Hakeim, Y.A., 2011. The effect of some toxic biogenic amines on the quality of some meat products with a trial to reduce its levels. Assiut Veterinary Medical Journal 57, 26-46.

FAO, 2013. Food and agriculture organization of the united nation for world without hunger. AGA Webmaster.

Faten, S.H., Hassan, M.A., Amany, M.S., ElWakeel, M.E., 2011. Demonstration of biogenic amines in fast foods. Benha veterinary medical journal 22, 230-237.

Fletcher, G.C., Summers, G., van Veghel, P.W., 1998. Levels of histamine and histamineproducing bacteria in smoked fish from New Zealand markets. J Food Prot 61, 10641070.

Gençcelep, H., Kaban, G., İrfan Aksu, M., Öz, F., Kaya, M., 2008. Determination of biogenic amines in sucuk. Food Control 19, 868-872.

Giroto, J.M., Masson, M.L., Haracemiv, S.M.C., 2010. Biogenic amines in sausages and other foods. Brazilian Journal of Food Technology 13, 1-10.

Krause, I., Bockhardt, A., Neckermann, H., Henle, T., Klostermeyer, H., 1995. Simultaneous Determination of Amino-Acids and Biogenic-Amines by Reversed-Phase HighPerformance Liquid-Chromatography of the Dabsyl Derivatives. Journal of Chromatography A 715, 67-79.

Kurt, S., Zorba, O., 2010. Biogenic amine formation in Turkish dry fermented sausage (sucuk) as affected by nisin and nitrite. 
Journal of the Science of Food and Agriculture 90, 2669-2674.

Pinho, O., Ferreira, I.M.P.L.V.O., Mendes, E., Oliveira, B.M., Ferreira, M., 2001. Effect of temperature on evolution of free amino acid and biogenic amine contents during storage of Azeitao cheese. Food Chemistry 75, 287291.

Rekka, M.H.A. 2002. Studies on some chemical substances in some meat products in relation to public health hazardM V Sc., Zagazig University.

Triki, M., Jimenez-Colmenero, F., Herrero, A.M., Ruiz-Capillas, C., 2012. Optimisation of a chromatographic procedure for determining biogenic amine concentrations in meat and meat products employing a cation-exchange column with a post-column system. Food Chemistry 130, 1066-1073.

Vinci, G., Antonelli, M.L., 2002. Biogenic amines: quality index of freshness in red and white meat. Food Control 13, 519-524.

WHO, 2010. Dietary Exposure Assessment of Chemicals in Food. World Health Organization, Maryland, USA, 61.

Wigand, P., Blettner, M., Saloga, J., Decker, H., 2012. Preventing headaches and other health problems due to biogenic amines in wine Prevalence of wine intolerance: results of a survey from Mainz.Germany Deutsches Ärzteblatt International, from universities. Journals, and other organizations 109, 437 444. 